\title{
Reflection of Education Administrators' Ethical Values on Organizational Culture: Case of Plato and Kant
}

\author{
Emel Sünter ${ }^{1}$, Tayfun Yörük ${ }^{2, *}$, Reyhan Şekerci ${ }^{3}, \&$ Süleyman Karataş ${ }^{4}$ \\ ${ }^{1}$ Faculty of Religion, Iğdır University, Turkey \\ ${ }^{2}$ Faculty of Applied Sciences, Akdeniz University, Turkey \\ ${ }^{3}$ Ministry of National Education, Turkey \\ ${ }^{4}$ Faculty of Education, Akdeniz University, Turkey \\ *Correspondence: Faculty of Applied Sciences, Akdeniz University, Turkey. E-mail: tayfun@akdeniz.edu.tr
}

Received: May 29, $2020 \quad$ Accepted: July 2, $2020 \quad$ Online Published: October 14, 2020

doi:10.5430/wje.v10n5p89 URL: https://doi.org/10.5430/wje.v10n5p89

\begin{abstract}
The purpose of this study is to reveal the views of administrators on the assessment of education administrators within the context of ethical values and their reflection on organizational culture. Ten administrators who were determined using convenience sampling which is one of purposeful sampling methods, participated in the study which was conducted using qualitative research method. Qualitative research technique was used in the research and it is used in one of the qualitative research designs, phenomenological design. Considering in terms of education administration; ethical rules to be possessed by today's school administrators were tried to be revealed on the basis of key concepts such as Plato's "wisdom, courage, moderation and justice" concepts and Kant's "duty, principle, will power, liability, law and rule" concepts according to his deontological theory, in accordance with the results acquired during the interview based on the application. According to the results of the research, it is possible to say that Plato's four key concepts of "Wisdom, bravery (courage), measure and justice." Are adopted more by school administrators. It is seen that the virtues of flour are generally adopted but in practice, Kant's Deontological theory is put into practice. In addition, it is considered that every step in the direct management of the characteristics of the school administrator and the effects of the administrator in the ethical context directly affect the organizational climate.
\end{abstract}

Keywords: ethics, virtue, organizational culture, administrators' views

\section{Introduction}

The world of thought of today's human beings and their life experiences seem to be quite different from other ages. Because humans have had to anthropologically carry the genetic codes (traditions/habits) of life experiences from the past on one hand and adapt to new situations (scientific and technological developments) forming in the outer world, on the other. This ambivalent tendency of humans subjects them to a new problem in every area of life. The best place for solving this problem is schools. Schools should be able to remove this problem of humans and enable them to adapt to the conditions of the advancing world.

Therefore, it has automatically become compulsory to develop methods and techniques that may increase individual and social utility for humans. To do that, it is necessary to provide some methods and techniques, as well as some conditions. Among these conditions, the need for individuals (personnel) with this consciousness comes first. In order to solve this problem, it is possible to find an answer to these questions in terms of philosophical knowledge, in the context of ethics. Why ethics? Because ethics produces ideas for humans to adapt to life and to draw a peaceful life route. Thus, in the context of ethics, determining the qualities to be possessed by school administrators who are the leaders of school, may also bring a solution to a part of this problem. As long as the school administrator's behaviors are in accordance with principles in the context of ethics, there will be adaptation in the school system. In other words, education administrator's ethical consistency and high qualification would thoroughly increase the school adjustment and success, which will result in an increased quality of life and education level.

Ethics exists to determine the conceptual framework of a person's happiness. In his work titled Republic; Plato, one 
of the philosophers mentioning the concept of ethics for the first time in Ancient Age, stated that righteousness was a prerequisite for being happy (Platon, 2002). The highest good is a mixture of "moderation, beauty (esthetics), truth and knowledge" (Cevizci, 2013). By this way, the person becomes virtuous. Virtuousness includes four qualities: Wisdom, courage, moderation and justice. Among these four virtues/qualities, the most superior one is justice. Plato's approach stands valid for qualities to be possessed by today's humans, as well (Özlem, 2010).

Ethical theories have progressed considerably since Ancient Age until today. The first ethical theories of modern age were presented by Newton, Copernicus, Galileo, and Kepler in the 17th century. In modern age, significant names such as Leibniz, Hobbes and Kant suggested ideas about morals (Magee, 2001). According to the deontological ethics theory among these theories; considering the conceptual framework of the administrator's qualities from the viewpoint of school administration, the qualities are encountered as ethical rules to be possessed by today's school administrators. Key concepts in the literature were assessed on the basis of key conceptions such as "duty, principle, will power, liability, law and rule", in the context of the deontological ethics theory. The deontological ethics theory is the Kant's philosophical discipline that keeps human mind at the highest principle and is grounded on autonomy, which forms moral life (Kant, 1994; Kenny, 2006). Also rather than the rules formed by different religions, deontological ethics is considered as a philosophical discipline centers upon intellectual aspect diverging from coincidences and the power of natural law (Cassirer, 1996).

On the other hand, two things are particularly stressed in modern education; resettling every individual in society and developing individual personality traits. Concerning education administration, social-pedagogical and administrative approaches questioning the role of leaders (Walidin, 2016), as well as organizational culture are evaluated as important factors for analyzing an organization in various contexts (Barney, 1986; Cameron and Quinn, 2005; Gordon \& DiTomaso, 1992; Marcoulides \& Heck, 1993; Wilkins and Ouchi, 1983). The concept of organizational culture is originated from the theory of culture and is among the most popular publications in the area of cultural studies. Organizational studies deal with various dimensions of social and organizational culture, focus on leadership applications in organizations and use some different dimensions of group leadership that are of prime importance for organizational cultures. Organizational culture, as a separable structure from social culture, has been subjected to research for years and various models have been developed in different disciplines (Tsui, Nifadkar, and Ou, 2007; Meyer, Tsui, \& Hinings, 1993).

Some common organizational culture models, which clarify how and why social culture is different from organizational culture and are often applied or attributed to by a number of scientists, stress their theoretical bases and offer them to us (Dauber, Fink, and Yolles, 2012). The idea that organizations may have certain cultures has often been investigated in a wide range of publications on strategy and job politics, organizational behavior and theory. Although some studies state that there is no solid theoretical basis for the concept of organizational culture, only a little effort has been made to bring relevant concepts in cultural anthropology into the area of management and organization. Thus, majority of the studies have three directions: Firstly, to provide the typology of schools of thought in cultural anthropology in order to understand various and complex cultural theories propounded in this field; secondly, to associate these different points of view with current concepts of organizational culture which exists in the management and organization literature either explicitly or latently; thirdly, to gather insights and findings acquired from the studies, in order to offer an integrated concept of organizational culture as a useful metaphor to examine the deterioration, adaptation and radical change processes in complex organizations (Allaire and Firsirotu, 1984).

Schein's (1985) model in which he separates organizational culture into 3 parts as; assumptions, values and behaviors, provides a framework to discuss the dynamism of organizational cultures. As well as collecting the cultural data and analyzing the cultural dynamics model, its effects on the future theoretical development are presented (Mary JoHatch, 1993). The study ends by offering "conceptual tools" to interpret culture (symbol, intellectual systems, myths and rituals) and how to use them in analyses (Meek, 1988; Hofstede et al., 1990; Sagiv and Schwartz, 2007; Dauber, Fink and Yolles, 2012; Lund, 1993). In this respect, a few important matters are taken into consideration while examining organizational culture and the assessments on behaviors that are reflection of especially values dimension of organizational culture in this study: 1 . To what extent is organizational culture fed by ethical values? 2. Considering the consequences of organization members' personalities and behaviors; to what extent are they affected by the principles of organization and the principles of ethical values? 3. What should be presented for this impact to come out positively? 4. As a consequence, to what extent has this situation affected tasks requiring organizational actions in organizational culture?

From the viewpoint of these basic parameters; it was tried to determine to what extent education administrators 
coincided with the current approach or moral theories mentioned in practice, in terms of organizational culture. In other words, we examined the approach of a school administrator in the context of ethics. What is aimed here is to determine whether administrators who are the leader of school, possess qualities they are meant to possess in the context of ethics or not. By this way, a solution will be delivered to the possible practices of administrators with this qualification and today's humans in school life. Because these qualities of the administrator will directly affect every stage in the management. Also the effects of the administrator in the context of ethics will positively affect organizational climate. Therefore, the problem statement of the research is as follows:

What are the views of administrators on the assessment of education administrators and its reflections on organizational culture, in the context of ethics?

Looking at the literature, there are many studies involving the ethical behavior of school principals and still continue to be studied frequently (Bass, Frick, \& Young, 2018; DeMatthews \& Serafini, 2019; Eranil \& Ozbilen, 2017; Grissom, Blissett, \& Mitani, 2018; Froehlich, Burrell, Brown, \& Yelman, 2019; Karakuş, 2018; Karatas, 2019; Tal-Alon \& Shapira-Lishchinsky, 2020; Webster \& Litchka, 2020). However, when the studies conducted are examined in general, it is investigated that the majority of the school administrators addressed the ethical behaviors and how they are behaved in the face of ethical dilemmas in popular terms. The philosophical trend that ethical dilemmas and ethical behaviors addressed in studies belong to and their origins are relative to which principles are accepted in educational management. It is also common to believe that all ethical values generally accepted as good and correct should be adopted by educational administrators, but what is good or correct for school administrators? Which philosophical or educational philosophy is based on current or foundations? And, of course, the effects and contributions of these behaviors to the corporate culture are inevitable. However, when we look at the literature, there is almost no research that indicates which philosophical field comes from the substructure or which behaves in practice. For this reason, with this study, it is expected that the evaluation of the possible effects of the executive and ethical behaviors of education in the context of ethical theories (on Kant and Plato example) in terms of philosophical foundations of education.

\section{Method}

In this study, descriptive screening model, which tries to describe a case and a subject individually according to Karasar (2009), was used. In order to conduct the description profoundly, qualitative research technique was used in the study and the study was carried out in the phenomenological design which is among qualitative research designs (Turgut, 2009). Thus, the data in the study were collected using interview technique and a semi-structured interview form was prepared for this purpose.

\subsection{Sample Group}

Sample group in the study consisted of administrators working in Konyaalti district of the Antalya city. In addition, the convenience sampling, one of purposeful sampling methods, was used in the study. The participants were coded as administrators A1, A2, A3, A4, A5, A6, A7, A8, A9, and A10, according to the order of interviews (Kus, 2007; Mason J. 2002; Patton, 1990; Rubin and Rubin, 1995; Yildirim and Simsek, 2006). Examining the demographic characteristics of the administrators, it was seen that gender variables were equally distributed. Education level of the participants was mostly undergraduate and higher. The participants mainly consisted of senior and experienced administrators with a seniority of 10 years and over.

\subsection{Data Collection Tools}

The interview questions were prepared upon the literature review and examined by a field expert. Based on the feedback received from this interview, the interview questions were put into final form. These questions started with 5 main problems and were expressed as follows; 1 . To what extent is the corporate culture nourished by its ethical values? 2. When the results of the personality and behavior of the members of the institution are analyzed, how are they affected by the principles of the institution and the principles of ethical values? 3 . What should be put forward to make this effect positive? 4. How did the resulting situation affect the tasks that require organizational actions in the corporate culture? 5. In the context of ethics, how is the evaluation of educational managers and their reflection on the corporate culture realized? Later, in line with the answers coming from the pilot interviews, probe questions, namely sub-questions, were determined. 6 . The virtues of Plato and the general principles of Kantin's deontological theories in practice were asked to the participants. 7. They were asked to make an assessment of which virtues or roles came to the fore. 8. Finally, questions regarding the opinions of the managers about the evaluation of the education managers in the context of ethical theories and their reflections on the corporate culture are included. 10. 
Also asked which theory they adopted, and how they were put into practice. In this way, a total of 10 questions were reached. The participants who were considered to be interviewed were informed about the purpose of the study and the administrators demanding to participate in the study were determined on voluntary basis. The researcher took notes synchronously with the interviews. The interviews lasted for 30-50 minutes. They were conducted in administrator's offices between February and March 2020.

\subsection{Data Analysis}

In the study, the qualitative data acquired from the interviews were analyzed using content analysis, which includes the stages of coding, finding themes and organizing the data according to codes and themes (Balci, 2004; Yildirim and Simsek, 2011). The interviews recorded during the interviews were put in writing in the computer environment by the researchers. All the transcripted data acquired in the study was load on NVIVO 10.0 which is a computer software used to analyze qualitative data. Then, all the transcription were read many times and coded. During coding, various dimensions were determined in accordance with the purpose of the study and appropriate themes were determined for these dimensions. For the purpose of providing reliability of the analyses, the interview texts were recoded by another researcher. In order for validity and reliability to provide objectivity in a good qualitative research (Morse et al., 2002), a consensus was substantially achieved among codings of the researcher and another expert and it was concluded that the process of coding was conducted in a reliable way. These codings formed the basis for obtaining themes, the themes were found by interpreting these codings by the researchers.. These themes are presented in Table 2 in the Results section.

\section{Results}

This section includes results regarding the views of administrators on the assessment of education administrators within the context of ethical values and their reflection on organizational culture and interpretations of these results.

\subsection{Distribution of the Participants According to Demographic Characteristics}

Table 1 shows the distribution of the participants according to their age, gender, marital status, educational background, duration of professional service, duty, and staff status:

Table 1. Distribution of the Administrators According to Demographic Characteristics

\begin{tabular}{|c|c|c|c|c|c|c|c|c|c|c|c|c|c|}
\hline Variable & Code & $\mathrm{A} 1$ & $\mathrm{~A} 2$ & $\mathrm{~A} 3$ & A4 & A5 & A6 & A7 & A8 & A9 & $\mathrm{A} 10$ & $\mathrm{f}$ & $\%$ \\
\hline \multirow{3}{*}{ Age } & $22-42$ & & & & & & $\sqrt{ }$ & $\sqrt{ }$ & $\sqrt{ }$ & $\sqrt{ }$ & $\sqrt{ }$ & 5 & 50 \\
\hline & $42-60$ & & $\sqrt{ }$ & $\sqrt{ }$ & $\sqrt{ }$ & $\sqrt{ }$ & & & & & & 4 & 40 \\
\hline & $60+$ & $\sqrt{ }$ & & & & & & & & & & 1 & 10 \\
\hline \multirow{2}{*}{ Gender } & $\mathrm{F}$ & & & $\sqrt{ }$ & $\sqrt{ }$ & & & $\sqrt{ }$ & & $\sqrt{ }$ & $\sqrt{ }$ & 5 & 50 \\
\hline & M & $\sqrt{ }$ & $\sqrt{ }$ & & & $\sqrt{ }$ & $\sqrt{ }$ & & $\sqrt{ }$ & & & 5 & 50 \\
\hline Marital & $\mathrm{S}$ & & & & & & & & $\sqrt{ }$ & & $\sqrt{ }$ & 2 & 40 \\
\hline Status & M & $\sqrt{ }$ & $\sqrt{ }$ & $\sqrt{ }$ & $\sqrt{ }$ & $\sqrt{ }$ & $\sqrt{ }$ & $\sqrt{ }$ & & $\sqrt{ }$ & & 8 & 80 \\
\hline Educational & Undergraduate & & $\sqrt{ }$ & $\sqrt{ }$ & $\sqrt{ }$ & $\sqrt{ }$ & $\sqrt{ }$ & $\sqrt{ }$ & & & $\sqrt{ }$ & 7 & 70 \\
\hline Background & Postgraduate & $\sqrt{ }$ & & & & & & & $\sqrt{ }$ & $\sqrt{ }$ & & 3 & 30 \\
\hline \multirow{4}{*}{$\begin{array}{l}\text { Duration of } \\
\text { Professional } \\
\text { Service }\end{array}$} & 6-10 & & & & & & & & & & $\sqrt{ }$ & 1 & 10 \\
\hline & $11-15$ & & & & & & $\sqrt{ }$ & & $\sqrt{ }$ & V & & 3 & 30 \\
\hline & $16-20$ & & $\sqrt{ }$ & & & & & & & & & 1 & 10 \\
\hline & $20+$ & $\sqrt{ }$ & & $\sqrt{ }$ & $\sqrt{ }$ & $\sqrt{ }$ & & $\sqrt{ }$ & & & & 4 & 40 \\
\hline \multirow{2}{*}{ Staff Status } & Staffed & $\sqrt{ }$ & & $\sqrt{ }$ & & $\sqrt{ }$ & $\sqrt{ }$ & $\sqrt{ }$ & $\sqrt{ }$ & $\sqrt{ }$ & & 7 & 70 \\
\hline & Secondment & & $\sqrt{ }$ & & $\sqrt{ }$ & & & & & & $\sqrt{ }$ & 3 & 30 \\
\hline
\end{tabular}

As is seen in Table 1, half of the participants were either under or over 42 years of age. Genders were balancedly distributed and majority of them were married. Most of the administrators had a bachelor's degree. Most of them were staffed; whereas, a part of them were working with secondment.

The themes determined according to the views of the administrators on the assessment of education administrators within the context of ethics and their reflection on organizational culture, were as follows: 
Table 2. The Views of the Administrators on the Assessment of Education Administrators within the Context of Ethics and Their Reflection on Organizational Culture

\begin{tabular}{|c|c|c|c|c|c|c|c|c|c|c|c|c|c|}
\hline \multicolumn{2}{|c|}{ Theme } & A1 & $\mathrm{A} 2$ & A3 & A4 & A5 & A6 & A7 & $\mathrm{A} 8$ & A9 & A10 & $\mathrm{f}$ & $\%$ \\
\hline \multirow{3}{*}{ Plato's Virtues } & 1. Wisdom & & & $\sqrt{ }$ & $\sqrt{ }$ & $\sqrt{ }$ & & $\sqrt{ }$ & & $\sqrt{ }$ & $\sqrt{ }$ & 6 & 60 \\
\hline & 2. Courage & & & $\sqrt{ }$ & & & & & & & & 1 & 60 \\
\hline & 3. Moderation & & & $\sqrt{ }$ & $\sqrt{ }$ & $\sqrt{ }$ & & & & & $\sqrt{ }$ & 4 & 40 \\
\hline \multirow{6}{*}{$\begin{array}{l}\text { Kant's Deontological } \\
\text { Theory }\end{array}$} & 4. Justice & & & & & & & & & & $\sqrt{ }$ & 1 & 10 \\
\hline & 5. Duty & $\sqrt{ }$ & $\sqrt{ }$ & & & & $\sqrt{ }$ & $\sqrt{ }$ & & $\sqrt{ }$ & & 5 & 50 \\
\hline & 6. Principle & $\sqrt{ }$ & $\sqrt{ }$ & & $\sqrt{ }$ & $\sqrt{ }$ & & $\sqrt{ }$ & $\sqrt{ }$ & $\sqrt{ }$ & & 7 & 70 \\
\hline & 7. Will Power & $\sqrt{ }$ & $\sqrt{ }$ & & & $\sqrt{ }$ & & $\sqrt{ }$ & $\sqrt{ }$ & & & 5 & 50 \\
\hline & 8. Liability & $\sqrt{ }$ & $\sqrt{ }$ & & & $\sqrt{ }$ & $\sqrt{ }$ & $\sqrt{ }$ & $\sqrt{ }$ & $\sqrt{ }$ & & 7 & 70 \\
\hline & 9. Law and Rule & $\sqrt{ }$ & $\sqrt{ }$ & & $\sqrt{ }$ & $\sqrt{ }$ & $\sqrt{ }$ & $\sqrt{ }$ & $\sqrt{ }$ & $\sqrt{ }$ & & 8 & 80 \\
\hline
\end{tabular}

The data obtained from the interviews were coded in the literature, in accordance with the general principles of Plato's Virtues and Canteen Deontological Theory. Looking at the findings in general; It is remarkable that the participants talk more about Kant's Deontological Theory. Placing the principles of "homework, principle, will, obligation, law and rules" identified with management overshadow Plato's virtues in similar themes. On the contrary, it is quite thought-provoking that the managers' pragmatist skills are respected. The views of the administrators on the assessment of education administrators within the context of ethics and their reflection on organizational culture, were as follows:

"In organizations where an order is tried to be formed, organizational culture is more important than any other place. But if you keep replacing administrators this often or every new administrator demands to leave, it will undoubtedly be very difficult to form organizational culture. Above all, a administrator is the memory of an organization. Thus, this means that continuous replacement will destroy the memory and start it all over. In this respect, I certainly believe the necessity of minimizing especially administrator replacement in order to form organizational culture. Because as a administrator, you have some duties and liabilities, which will be fulfilled in the long term. Because you invest in humans. Just as things begin to settle down, those assigned leave. You or he won't even have time to show your or his virtues." A1 $(5,6,7,8,9)$

"I believe moral virtues are the last thing considered in administrators. In other words they remain in the background, compared to Kant's duties, principles and liabilities. Considering administration exams, it is seen that seventy five percentage of the exam subjects are about legislation, basic duties and liabilities, penalties ... In education, ethics is barely mentioned. Noone will succeed if it is asked in exams. Moral virtues remain so much in the background that organizations have no culture at all." A2 $(5,6,7,8,9)$

"You have to wait at least six months in order for a place to have a certain culture. The same goes for adapting to a place. You observe that place for a while and try to internalize its organizational culture. That's why administrators here are never paid attention to. They know that administrators will be replaced anyway and very often. Some of them don't even address remarks to them. In such an organizational communication, there is no way for you to observe and understand individuals' moral values and virtues. There are just duties and responsibilities...” A6 $(5,8,9)$

"To me organizational culture is like organizational memory. For example, there is a situation I encounter so often and find so strange. Former administrators used to reset their computers, leave documents and files disorganized and change the place of instructions regarding operation. Especially those who do not want to resign do this very often. I think it damages organizational culture. Administrators doing this force us to learn everything from the beginning and have a hard time. Learning is not difficult. Anyone who is ambitious enough can do and learn everything. What matters is to be permanent in your work, now and in the future. Do you think this fits into moral virtue? A administrator's morals always comes first. We have a famous saying; corruption starts at the top.. "A8 $(6,7,8,9)$

According to A1, A2, A6 and A8 frequent changes of school principals affect organization memory negatively. This 
structure of organizational culture is almost non-existent. In this relationship, the tendency of managers to have ethical values and follow an educational philosophy is low. The principles of Kant's duties, responsibilities, principles and principles are more than expected from current governments.

"The problem here is that no culture has been formed in the organization. If there is a present organizational culture and it is maintained, then there will be no problem. Indeed, every new administrator will add and even offer something. Unless there is culture, there will be no morals. We have a famous saying; to do something with morals. That's what we lack. Indeed being sharp, smart and clever and using others as a step gain more favor in desirable things like wisdom, courage and moderation, today. That's why moral values are now tried to be reminded." A3 $(1,2,3)$

"I know that if there is a certain organizational culture in a school, everything will be fine. Otherwise you are toast. Lack of organizational culture means that you will have to rebuild the school from zero. Because there is a certain culture. If there is culture, this means that employees in that organization have a certain level of moral maturity." A4 $(1,3,6,9)$

"Pay a particular attention to organizations where a variety of branches such as paid, contracted, temporary teachers who work with assignment, are present together for a short time. These organizations have the greatest amount of moral hazard. They lack virtuousness. Because administrators and employees know that they are together only for a short time. Therefore they never pay attention to virtuous behaviors. On the other hand teachers who have been working in the same school for many years, have kindness, graciousness and all. That's how administrators and schools should be." A5 $(1,3,6,7,8,9)$

"I think the most important thing is justice. If there is justice, there is everything. Look at teachers and administrators. They all complain about injustice. But they miss something; everyone wants justice for themselves. They ignore another person's rights. At that point moderation or maybe wisdom should step in. The person should also have a universal level of morals. " A10 $(1,3,4)$

According to the participants numbered A3, A4, A5 and A10 lack of organizational culture is linear with moral deprivation. According to the participants, there is no organizational culture at the present time, and therefore having moral virtues is a situation that remains only in such research and theories. Although executives with superior virtues are expected in practice, such as Plato's virtues, there is no equivalent in practice because it is difficult to measure, observe and distinguish. In fact, he emphasized that Kant's deontological theory should not only be evaluated as a duty and obligation as well as the virtues of Plato, and that Kant's principles are as important and necessary as Plato's virtues.

"To me organizational culture is very important. I show particular attention to form this culture everywhere I go. Because for me everything has to be organized and systematic. If things are disorganized and unsystematic, I won't be able to work. The same goes for moral understanding. I pay a particular attention to whether employees regard occupational ethics and assistant principals have ethical consciousness or not. I even warn them if I see an inappropriate behavior. Principals are conscious due to their liabilities and duties, however assistant principals may sometimes behave carelessly because they consider that principals have the main responsibility. Moral virtue is not necessary only for principals. Every individual is responsible for the ethical dimension of their own behaviors. " $A 7(1,5,6,7,8,9)$

"I think organizational culture is a very important issue. For example, we used to have a principal here. We still conduct applications in his way. Indeed, other organizations consult us to learn how to do things. We are called even from outside the city and we share our methods with them. This makes us proud. It shows administrators' wisdom level. It is a virtue enabling you to learn and share. However, the current operation involves so many duties, principles and responsibilities that they remain in the background." A9 $(1,5,6,8,9)$

A7 and A8 are the participants who adopt the views of both philosophers and state that values such as Kantin's duties, responsibilities, obligations, principles and principles must be found together in order to form an organizational culture in an organization, but unfortunately they cannot see it in existing institutions.It is possible to say that Plato's four key concepts, which are explained in the theoretical section, "Wisdom, bravery (courage), scale and justice." Are more adopted by school administrators. It is seen that the virtues of flour are generally adopted but in practice, Kant's Deontological theory is put into practice. 


\section{Conclusion and Discussion}

Current studies on organizational culture present two themes. On one hand, management organizations and institutions promote one-sided emotions that all participants accept as common values and protect. Alternatively, other studies define organizations as structures using collective values for sectional advantage and containing potentially divided interests. A common assumption for both perspectives is that organizational events have single and stable meanings for all parties. Organizational culture is either related to common unity or common division. It is argued that emotions and events celebrating unique identity of mechanists in a firm using empirical materials, are also a means for the claim of boundary and distinction between interests in this group. Multiple interpretations can be made for organizational events and processes. This leads to some generalizations suggesting that organizational culture is defined especially by limitation processes among intragroup interests (Young, 1989).

In another study examining the two temporal elements of organizational culture -polychronicity and velocity valuesand their effects on organizational performance, it was stated that the examination of these dimensions of culture and their effects on firm effectiveness was valid particularly for leaders who were responsible for the implementation of firm culture as one of the strategical resources of firms. The effects of these temporal elements were examined individually and in the context of excessively competitive industries (Onken, 1999). In a study comparing the preferences of newcomers with organizational culture perceptions and organizational culture preferences of auditors and their peers for the sake of organizational culture, newcomers were employed and cultural preferences and perceptions of auditors revealed the two aspects of organizational culture: anxiety for people and concern for achieving a goal. The results revealed that newcomers' anxiety about their superiors was related to their organizational commitment and turnover target (Van Vianen, 2000). In addition, main strategy of an organization was found to be dependent on the protection of cultural identity in terms of valid values. From collective success experience to consistent values and to adaptation and productivity; organizational culture sustains culture. However unless the alternatives allowed by culture are appropriate for new problems, organizational culture becomes a vicious cycle obstructing change. As a consequence, there might be a distinct cultural change, cultural revolution or a cultural increment (Gagliardi, 1986).

On the other hand, ethics (Ethics/Ethica/Morals Science) investigates the "good", as well as the nature, essence and sources of good behaviors. It is considered a branch of traditional philosophy seeking an answer to the question "How should we live?", as well as complementary questions such as "What kind of life is a good life for a person?", "What kind of life is worth living?", "What needs to be chosen to lead a proper life?". Thus, ethics develops a method and an answer for all kinds of possible problems in every area of human life. The purpose here is to determine how a person can be more peaceful and happy. There are different factors bringing moral issues to forefront in modern societies. However, the most distinct reason is scientific developments. Today's humans have a scientific/positive perspective of life. However, it is obvious that science also brings along mechanism. Philosophy has never abstained from humans' effort of thinking and focusing on understanding the universe in the face of this progress/mechanism of science. Ethics, as a product of this effort has continued to develop in every era.

In his work titled Republic; Plato, one of the philosophers mentioning the concept of ethics for the first time in Ancient Age, stated that righteousness was a prerequisite for happiness. The highest good is a mixture of "moderation, beauty (esthetics), truth and knowledge". By this way, the person becomes virtuous. There are four qualities in virtuousness: Wisdom, courage, moderation and justice. Among these four qualities, the most superior one is justice. Plato's approach stands valid for qualities to be possessed by today's humans, as well. However, according to the results of the study, the participants mainly mentioned Kant's Deontological Theory, which is highly interesting. "Duties, principles, will power, liabilities, laws and rules" that were identified with management, overshadowed Plato's virtue principles, which is noteworthy. Also, in the themes determined, Plato's virtues were barely mentioned and the participants stated that today's administrators' pragmatist skills were estimable, which is thought-provoking. However, assessing the present approaches of school administrators and the effect of these approaches on the present organizational culture by adopting Plato's four key concepts, "wisdom, courage, moderation and justice" as a conceptual framework in general; it is of prime importance to deliver a solution to possible practices of today's humans in school life by determining whether or not administrators who are the leader of school, possess qualities they are meant to possess in the context of ethics. Because these qualities of the administrator will directly affect every stage in the administration. Also the effects of the administrator in the context of ethics will positively affect organizational climate. 


\section{References}

Allaire, Y., \& Firsirotu, M. E. (1984). Theories of organizational culture. Organization studies, 5(3), 193-226. https://doi.org/10.1177/017084068400500301

Ayas, A., Haluk, Ö., Calık, M., Cimer, A., Ekiz, D., Yigit, N., \& İskurt, E. (2014). Eğitim bilimine giriş. Ankara: Pegem Akademi.

Barney, J. ( 1986 ). Örgüt kültürü: Rekabet avantajı kaynağı olabilir mi? Yönetim Akademisi Dergisi, 3, 656-665. https://doi.org/10.2307/258317

Bass, L., Frick, W. C., \& Young, M. D. (Eds.). (2018). Developing Ethical Principles for School Leadership: PSEL Standard Two. UK: Routledge.

Balci, A. (2004). Sosyal bilimlerde araştırma. Ankara: Pegem Yayıncılık.

Cameron, K. S., \& Quinn, R. E. (2005). Diagnosing and Changing Organizational Culture. San Francisco, CA: Jossey-Bass.

Cassier, E. (1996). Kant's Life and Thought. İstanbul: İnkılap Yayınları. (In Turkish).

Cevizci, A. (2013). Uygulamalı Etik. İstanbul: Say Yayınları.

Dauber, D., Fink, G., \& Yolles, M. (2012). A Configuration Model of Organizational Culture. SAGE Open. https://doi.org/10.1177/2158244012441482

DeMatthews, D. E., \& Serafini, A. (2019). Do good principals do bad things? Examining bounds of ethical behavior in the context of high-stakes accountability. Leadership and Policy in Schools, 1-20. https://doi.org/10.1080/15700763.2019.1668023

Eranil, A. K., \& Ozbilen, F. M. (2017). Relationship between School Principals' Ethical Leadership Behaviours and Positive Climate Practices. Journal of Education and Learning, 6(4), 100-112. http://doi.org/10.5539/jel.v6n4p100

Froehlich, I. I., Burrell, T., Brown, B., \& Yelman, A. (2019). Principals: Democratic Ethical Leadership Versus Behaviors of Conventional School Leaders. Applying Turbulence Theory to Educational Leadership in Challenging Times: A Case-Based Approach, 89.

Gagliardi, P. (1986). The Creationand Change of Organizational Cultures: A Conceptual Framework. OrganizationStudies, 7(2), 117-134. https://doi.org/10.1177/017084068600700203.

Gordon, G. G., \& DiTomaso, N. (1992). Predicting Corporate Performance From Organizational Culture. Journal of Management Studies, 29, 783-798. https://doi.org/10.1111/j.1467-6486.1992.tb00689.x

Grissom, J. A., Blissett, R. S., \& Mitani, H. (2018). Evaluating school principals: Supervisor ratings of principal practice and principal job performance. Educational Evaluation and Policy Analysis, 40(3), 446-472. https://doi.org/10.3102/0162373718783883

Hofstede, G., Neuijen, B., Ohayv, D. D., \& Sanders, G. (1990). Measuring organizational cultures: A qualitative and quantitative study across twenty cases. Administrative Science Quarterly, 35, 286-316. https://doi.org/10.2307/2393392

Kant, I. (1995). Grundlegung zur Metaphysik der Sitten. Ankara: Türkiye Felsefe Kurumu Yayınları. (In Turkish)

Karakuş, M. (2018). The moderating effect of gender on the relationships between age, ethical leadership, and organizational commitment. Journal of Ethnic and Cultural Studies, 5(1), 74-84. http://dx.doi.org/10.29333/ejecs/106

Karasar, N. (2009). Bilimsel araştırma yöntemi. Ankara: Nobel Yayın Dağıtım.

Karatas, I. H. (2019). Principles of professionalism in school principalship. Universal Journal of Educational Research, 7(2), 588-599. https://doi.org/10.13189/ujer.2019.070232

Kus, E. (2003). Nicel-nitel araştırma teknikleri. Ankara: Anı Yayıncılık.

Kus, E. (2007). Nicel-Nitel Araştırma Teknikleri (2dn ed.). Ankara: Anı Yayıncılık.

Lund, D. B. (2003). Organizational culture and job satisfaction. Journal of business \& industrial marketing, 18(3), 219-236. https://doi.org/10.1108/0885862031047313

Magee, B. (2001). The Great Philosophers: An Introduction to Western Philosophy. İstanbul: Paradigma Yayınları. (In 
Turkish).

Marcoulides, G. A., \& Heck, R. H. ( 1993 ). Organizational culture and performance: Proposing and testing a model. Organization Science, 4, 209-225. https://doi.org/10.1287/orsc.4.2.209

Hatch, M. J. (1993). The Dynamics of Organizational Culture. Academy of Management Review, 18(4), 657-693. https://doi.org/10.5465/amr.1993.9402210154

Mason J. (2002). Qualitative researching (2nd ed.). London: Sage Publications Ltd.

Meek, V. L. (1988). Örgüt Kültürü: Kökenleri ve Zayıf Yönleri. Organizasyon Çalışmaları, 9(4), 453-473. https://doi.org/10.1177/017084068800900401

Meyer, A. D., Tsui, A. S., \& Hinings, C. R. (1993). Configurational approaches to organizational analysis. Academy of Management Journal, 36, 1175-1195. https://doi.org/10.5465/256809

Morse, J. M., Barrett, M., Mayan, M., Olson, K., \& AndSpiers, J. (2002). Verification strategies for establishing reliability and validity in qualitative research. International Journal of Qualitative Methods, 1(2), 13-22. https://doi.org/10.1177/160940690200100202

Onken, M. (1999). Temporal elements of organizational culture and impact on firm performance. Journal of ManagerialPsychology, 14(3), 231-244. https://doi.org/10.1108/02683949910263756

Özlem, D. (2010). Etik: Ahlak Felsefesi. İstanbul: Say Yayınları.

Patton, M. Q. (1990). Qualitative evaluation and research methods. London: Sage Publication.

Patton, M. Q. (1990). Qualitative evaluation and research (2nd ed.). California, USA: SagePub. Inc.

Platon. (2002). Politeia. İstanbul: Sosyal Yayınları. (In Turkish)

Rubin, H., \& Rubin, I. (1995). Qualitative interviewing: The art of hearing data. ThousandOaks, CA: Sage.

Sagiv, L., \& Schwartz, S. H. (2007). Cultural values in organisations: Insights for Europe. European Journal of International Management, 1, 176-190. https://doi.org/10.1504/EJIM.2007.014692

Schein, E. H. (1985). Organizational culture and leadership. San Francisco, CA: Jossey-Bass.

Tal-Alon, N., \& Shapira-Lishchinsky, O. (2020). Employing teachers with disabilities: A multifaceted prism of school principals' ethical dilemmas. Educational Management Administration \& Leadership. https://doi.org/10.1177/1741143220921185

Tsui, A. S., Nifadkar, S. S., \& Ou, A. Y. (2007). Cross-national, cross-cultural organizational behavior research: Advances, gaps, and recommendations. Journal of Management, 33, 426-478. https://doi.org/10.1177/0149206307300818

Turgut, Y. (2009). Verilerin kaydedilmesi, analizi, yorumlanması: nicel ve nitel. In Tanrı̈öğen, A. (Ed.), Bilimsel araştırma yöntemleri (pp. 193-247). Ankara: Anı Yayıncılık.

Van Vianen, A. E. (2000). Person-Organization Fit: The Match Between Newcomers' and Recruiters' preferences For $\begin{array}{lllll}\text { Organizational Cultures. } & \text { Personnel }\end{array}$ https://doi.org/10.1111/j.1744-6570.2000.tb00196.x

Webster, K., \& Litchka, P. (2020). Planning for Effective School Leadership: Teachers' Perceptions of the Leadership Skills and Ethical Behaviors of School Principals. Educational Planning, 27(1), 31-47.

Wilkins, A. L., \& Ouchi, W. G. (1983). Efficient cultures: Exploring the relationship between culture and organizational performance. Administrative science quarterly, 28(3), 468-481. https://doi.org/10.2307/2392253

Yıldırım, A., \& Simsek, H. (2006). Sosyal bilimlerde araştırma yöntemleri (6th ed.). Ankara: Seçkin Yayıncılık.

Yıldırım, A., \& Simsek, H. (2011). Sosyal bilimlerde nitel araştırma yöntemleri (8th ed.). Ankara: Seçkin Yayıncılık.

Young, E. (1989). On the Naming of the Rose: Interests and Multiple Meanings as Elements of Organizational Culture. Organization Studies, 10(2), 187-206. https://doi.org/10.1177/017084068901000204

\section{Copyrights}

Copyright for this article is retained by the author(s), with first publication rights granted to the journal.

This is an open-access article distributed under the terms and conditions of the Creative Commons Attribution license (http://creativecommons.org/licenses/by/4.0/). 